Journal of Maternal and Child Health (2016), 1(3): 170-178

https://doi.org/10.26911/thejmch.2016.01.03.04

\title{
Path Analysis on the Effect of Breastfeeding Complementary Food Pattern, Maternal Schooling, Family Income, and Birthweight, on Nutritional Status in Children Underfive
}

\author{
Ahmitta Laila Nurjanah'), Didik Tamtomo²), Yulia Lanti Retno Dewi²) \\ ${ }^{1)}$ Masters Program in Public Health, Universitas Sebelas Maret \\ 2)Faculty of Medicine, Universitas Sebelas Maret
}

\begin{abstract}
Background: Indonesia is one among the 17 countries with the highest prevalence of stunting, wasting, andoverweightin children under five. In 2013, the prevalence of moderate undernutrition and severe undernutrition was $13.9 \%$ and $5.7 \%$, respectively, in children under five. The prevalence of stunting was $19.2 \%$. The period from birth to 2 years is so called as a sensitive period when the deleterious exposure and inadequate food intake can result in negative impact on the quality of the future generation. This study aimed to analyze the effect of breastfeeding complementary food pattern, maternal schooling, family income, and birthweight, on nutritional status in children underfive.

Subjects and Method: This was an analytic observational with cross sectional design. This study was carried out in Klaten, Central Java from December 2016 to January 2017. A total sample of 120out of 1236 mothers who had children aged 6-24 months wereselected for this study by multistage sampling. The dependent variable was nutritional status measured in weight for age. The independent variables were breastfeeding complementary food pattern, maternal schooling, family income, and birthweight.The data were collected by a set of questionnaire and analyzed with path analysis model on IBM SPSS AMOS 22.

Results: The path model showed goodness of fit with $\mathrm{CMIN}=1.18 ; \mathrm{p}=0.002 ; \mathrm{GFI}=0.99$; NFI= 0.98; CFI $=1.00$; RMSEA $<0.001$. Breastfeeding complementary food pattern $(b=0.27 ; p=0.002)$ and birthweight $(b=0.25 ; p=0.004)$ showed direct positive and statistically significant effect on weight fo age score. Family income $<R p 1,400,000(b=0.06 ; p=0.481)$ showed direct positive but statistically non significant effect on weight for age score.Maternal education showed positive and statistically significant effect on family income $(b=0.28 ; p=0.001)$.

Conclusion:Breastfeeding complementary food pattern and birthweight are important determinantof nutritional status as measured in weight for age in children under five. Maternal education has a positive effect on family income. Family income does not show its effect on nutritional status in this study.
\end{abstract}

Keywords: breastfeeding complementary food pattern, nutritional status, children under five

\section{Correspondence :}

Ahmitta Laila Nurjanah. Masters Program in Public Health, Universitas Sebelas Maret. Jl. Ir. Sutami 36A, Surakarta, Central Java 57126. Email: lailaarmella@gmail.com.

BACKGROUND
Nutrition contributes to the death of
children in the world which is about 3
million children and threatens the growth
and development of the body and brain of
children which can affect learning ability
while still a child and as an adult (IFPRI,

2016). The age of $o$ months to 2 years is a golden period, especially for toddlers growth, so if there is a disturbance at this time, if it cannot be fulfilled, it will affect the next period and will negatively affect the quality of future generations. This is consistent with the Barker Theory which 
explains that the beginning of life will affect the next stage of life (Ministry of Health RI, 2013; Murti, 2011).

According to the Ministry of Health (2016), Indonesia is included in 17 countries out of 117 countries that have three nutritional problems, namely stunting, wasting, and overweight in toddlers. Chronic malnutrition (stunted) causes irreversible growth failure, inhibits mental and physical development. In addition, malnutrition during this period is also associated with the risk of chronic diseases in adulthood, namely obesity, heart and blood vessel disease, hypertension, stroke and diabetes..

The prevalence of nutritional status of toddlers in Indonesia with malnutrition and malnutrition has not increased compared to 2010. Based on the results of the Basic Health Research (2013) research, health problems that occur at the age of toddlers include low birth weight (LBW) of 10.2\% which has decreased from in 2010 that was $11.1 \%$, the proportion of malnutrition which increased from $4.9 \%$ in 2010 to $5.7 \%$, the proportion of malnutrition which increased from $13.0 \%$ in 2010 to $13.9 \%$, the incidence of short-term infants (stunting) who experienced an increase from $17.1 \%$ in 2010 to $19.2 \%$ (Ministry of Health RI, 2013).

Understanding the nutritional status of toddlers can be done by monitoring or weighing toddlers. Weighing a toddler is done every month in various places such as posyandu, polindes, puskesmas, and other health care facilities. Monitoring the growth of toddlers is very important to determine the early growth of toddlers. According to the Central Java Province Health Profile (2012), the coverage of under-fives underweight (D / S) was 79\%. This is still below the national target of 83\%. The mortality rate in Central Java
Province in 2012 increased compared to 2011, which was $11.85 \%$. Toddlers who experience malnutrition were $4.88 \%$, while toddlers who experience poor nutrition were $0.06 \%$. Klaten Regency had a high incidence of malnutrition in 2012 at $0.63 \%$ and was the highest malnutrition incidence in Ex Karisidenan Surakarta, the second highest was in Sukoharjo District (0.53\%), and the third highest was in Boyolali District (0.51\%). As for the incidence of malnutrition, Klaten Regency was 3.68\%, this figure was higher than Boyolali District (3.28\%) and Karanganyar Regency (2.69\%).

Klaten Regency is one of the districts located in Central Java Province. In 2015, toddlers in Klaten District were weighed (D) totaling 66,465 , while for underfives reported a total of 83,241 . Based on this data, it is known that the percentage of under-fives weighed (D / S) is $79.8 \%$, this shows an increase compared to 2014 which was only $78.1 \%$. Even so, the coverage of under-five children in Klaten Regency is still below the Province of Central Java which reaches $81.3 \%$ (Klaten District Health Office, 2015).

Based on a preliminary study conducted at the Klaten District Health Office, in February 2016, the number of children under five was weighed in 34 Puskesmas totaling 67,628 infants. The number of children with severe malnutrition was 678 (1\%). The number of children under five was very short at 1,176 (1.7\%). The number of children under five was 63 (0.09\%). This data show the still high incidence of malnutrition in Klaten District.

Based on the description above, there are still various nutritional problems for toddlers so that early prevention and routine monitoring at the posyandu and other health facilities need to be conducted. 
Journal of Maternal and Child Health (2016), 1(3): 170-178

https://doi.org/10.26911/thejmch.2016.01.03.04

The formulation of the problem in this study is, whether there is any influence between complementary feeding patterns (MP-ASI), mother's education level, family income and infant's birth weight on the nutritional status of children. The purpose of this study was to analyze the effect of complementary feeding patterns (ASI), maternal education level, family income and infant birth weight on the nutritional status of children.

SUBJECTS AND METHOD

This was an analytic observational study with a cross sectional design. The study was conducted in Klaten, Central Java, from December 10, 2016 to January 5, 2017.

The study population was 1236 mothers who had children aged 6-24 months. The sampling technique used was

Table 1. Study Subject Characteristics

\begin{tabular}{ll}
\hline Characteristics & N (\%) \\
\hline Gender & \\
Male & $68(56.70 \%)$ \\
Female & $52(43 \cdot 30 \%)$ \\
Complementary feedingPattern & $42(35 \%)$ \\
Inappropriate & $78(65 \%)$ \\
Appropriate & \\
Maternal Education & $32(26.70 \%)$ \\
Low <Senior high school & $88(73.30 \%)$ \\
High $\geq$ Senior high school & \\
Family Income & $42(35 \%)$ \\
$<$ Minimum wage $(<1,400,000)$ & $78(65 \%)$ \\
$\geq$ Minimum wage $(\geq 1,400,000)$ & $13(10.80 \%)$ \\
Birth Weight & $107(89.20 \%)$ \\
BBLR $(<2500$ g) & \\
Normal ( $\geq 2500$ g) & $1 \quad(0.80 \%)$ \\
Nutritional Status (WAZ) & $13(10.80 \%)$ \\
Poor & $104(86.70 \%)$ \\
Fair & $2(1.70 \%)$ \\
Good & \\
\hline
\end{tabular}

\section{Path Analysis}

The results of the data processing was conducted using path analysis with the help of IBM SPSS AMOS version 22 program, obtained the following results: multistage sampling in which a sample of 120 mothers had toddlers 6 months-24 months.

The dependent variable was nutritional status weight for age (WAZ). The independent variables were complementary feeding pattern, maternal education, family income, and birth weight. The data were collected by questionnaire and medical record. The data were analyzed by path analysis run on SPSS Amos.

\section{RESULTS}

\section{Study Subjects Characteristics}

The results of the characteristics of the study subjects (Table 1) show different distributions. The description of the study subject is explained based on the characteristics, criteria, frequency (n), and percent (\%).

\section{a. Model Spesification}

Model specifications describe the effect of the relationship between the variables to be studied. There are some observed variables, namely pattern of complementary feeding, maternal education, family income, birth 
weight, and nutritional status of children weight for age.

\section{b. Model Identification}

This stage is calculated from the degree of freedom (df) which shows whether the path analysis can be done or not. It is presented as follows.

1) The total of observed variable: 5

2) Endogenous Variable : 2

3) Exogenous Variable : 3

4) The total of parameters: 7

The formula of degree of freedom is presented as follows: $\mathrm{df}=$ (the total of observed variable $\mathrm{x}$ (the total of observed variabel+1)/2 (endogenous variable + exogenous variable + the total of parameter $)=$ $(5 \times 6) / 2-(2+3+7)=3$.

The path analysis can be done if $\mathrm{df} \geq$ $o$, while in the identification of the model in the path analysis this time the df value is 3 (over-identified) which means that path analysis can be done.

\section{c. Model fit and estimation}

Figure 1 shows the structural model after estimating using IBM SPSS Amos 22, so that the values are obtained as shown. Indicators that indicate the suitability of the path analysis model are presented in Table 2. The results of path analysis show that there is a Goodness of Fit Measure obtained by the CMIN index fit of 1.184 with a value of $\mathrm{p}=0.757(>0.05) ; \mathrm{GFI}=0.99$ $(>0.90) ; \quad \mathrm{NFI}=0.98(>0.90) ;$ CFI 1.00 (>0.90); RMSEA<0.01 (<0.05), which means that the empirical model meets the specified criteria and is stated in accordance with the empirical data. Table 2 shows the results of pathway analysis of nutriational status of children (weight according to age).

Table 2. The results of path analysis on the association between complementary feeding pattern, maternal education, family income, birth weight, and nutritional status weight for age

\begin{tabular}{|c|c|c|c|c|c|c|}
\hline $\begin{array}{c}\text { Dependent } \\
\text { Variable }\end{array}$ & & Independent Variable & b & SE & $\mathbf{p}$ & $\boldsymbol{\beta}$ \\
\hline \multicolumn{7}{|l|}{ Direct Effect } \\
\hline WAZ & $\leftarrow$ & $\begin{array}{l}\text { Complementary feeding } \\
\text { pattern }\end{array}$ & 0.12 & 0.037 & 0.002 & 0.27 \\
\hline WAZ & $\leftarrow$ & Income & 0.07 & 0.100 & 0.481 & 0.06 \\
\hline WAZ & $\leftarrow$ & Birth weight ( $\geq 2500 \mathrm{~g}$ ) & 0.58 & 0.203 & 0.004 & 0.25 \\
\hline \multicolumn{7}{|c|}{ Indirect Effect } \\
\hline $\begin{array}{l}\text { Income } \\
\mathrm{N} \text { Observation }\end{array}$ & $\underset{20}{\leftarrow}$ & Education & 0.59 & 0.184 & 0.001 & 0.28 \\
\hline \multicolumn{7}{|l|}{ Fit Model } \\
\hline \multicolumn{7}{|c|}{$\mathrm{CMIN}=1.184 \mathrm{p}=0.757(\geq 0.05)$} \\
\hline \multicolumn{7}{|c|}{$\mathrm{GFI}=0.99 \quad(\geq 0.90)$} \\
\hline \multicolumn{7}{|c|}{$\mathrm{NFI}=0.98 \quad(\geq 0.90)$} \\
\hline \multicolumn{7}{|c|}{$\mathrm{CFI}=1.00 \quad(\geq 0.90)$} \\
\hline RMSEA $<0.01$ & 0.08 & & & & & \\
\hline
\end{tabular}

The results of path analysis indicate that there is a direct relationship between complementary feeding pattern and nutritional status (WAZ). Path coefficient value (b) which has not been standardized between the pattern of giving complementary feeding with nutritional status of child- ren (WAZ) is positive, that is equal to 0.12 with indigo S.E 0.037, and which has been standardized is 0.27 with a value of 0.002 , which is significant.

The results of path analysis indicate that there is a direct relationship between the income of families with nutritional 
status of children under five (WAZ). Path coefficient value (b) which has not been standardized between family income with nutritional status of children (WAZ) has a positive value that is equal to 0.07 with $\mathrm{SE}$ 0.10 , and that has been standardized is 0.06 with a value of 0.481 , declared nonsignificant.

The results of path analysis indicate that there is a direct relationship between birth weight and nutritional status of children (WAZ). Path coefficient value (b) which has not been standardized between baby's birth weight (2500 g) and nutritional status of children (WAZ) is positive, which is 0.58 with a value of $\mathrm{SE}=0.20$, and which has been standardized is 0.25 with $\mathrm{p}=$ 0.004 .
The results of path analysis indicate that there is an indirect relationship between the level of education of mothers with nutritional status of children (WAZ) through the variable between family income. Path coefficient value (b) that has not been standardized between the level of education of mothers with positive family income is equal to 0.07 with a value of S.E 0.100 , and which has been standardized is 0.06 with a value of $\mathrm{p}=0.481$.

\section{d. Specifications Model}

The model in this study was in accordance with the sample data as indicated by the saturation model and also the path coefficient which was more than zero and statistically significant, so the path analysis model was not necessary.

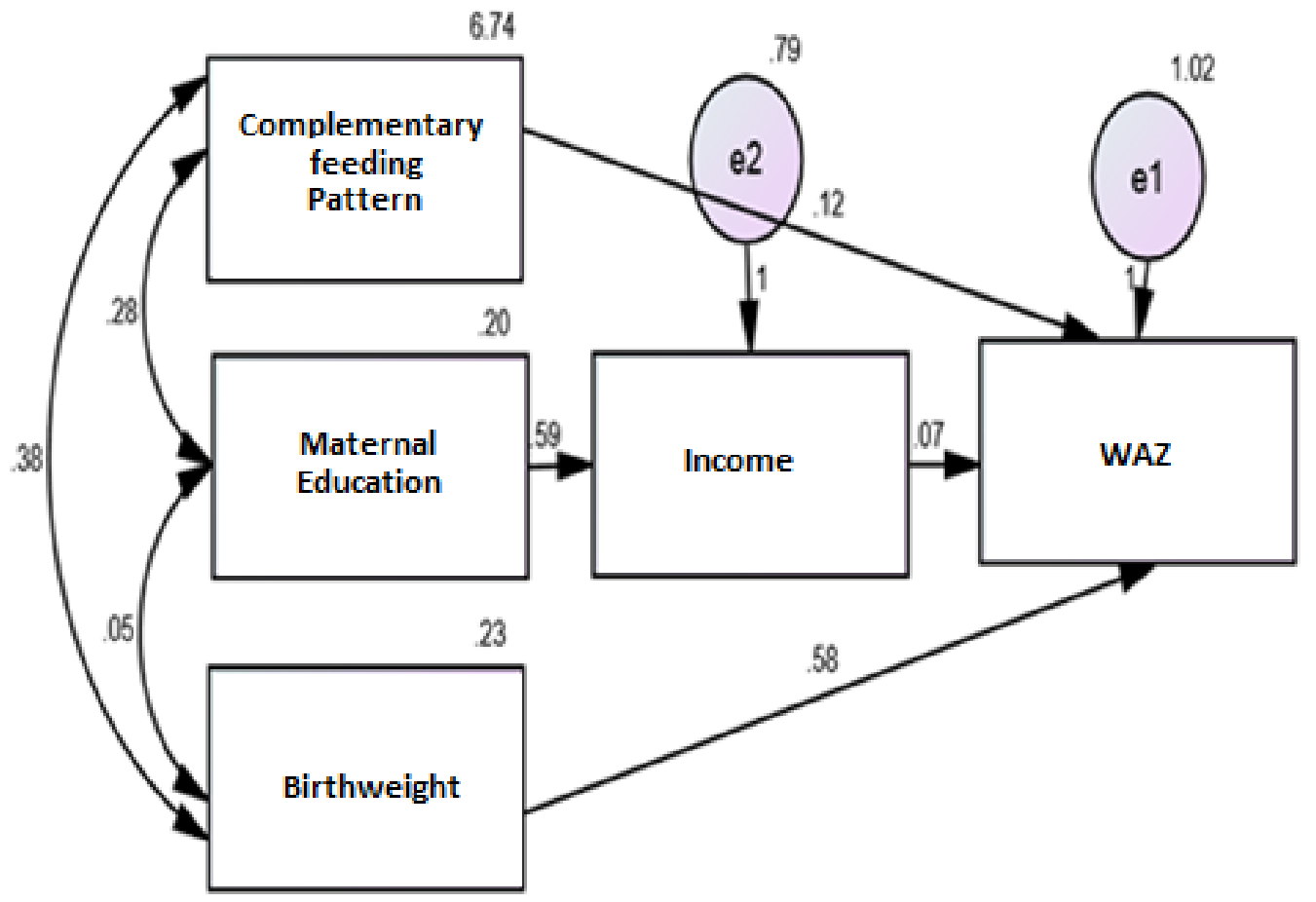

Figure 1. Structural Model with Unstandardized

\section{DISCUSSIONS}

1. The effect of relationship between complementary feeding pattern on children nutritional status

The result of this study showed that complementary feeding pattern has a direct and positive effect on children nutritional status. The complementary feeding pattern which was appropriate to the age of the toddler would affect toddlers' nutritional status. In this case,the toddlers got good and beneficial nutrition to fulfill the needs 
of the growth. Minister of Health RI andUnicef (2013) recommend exclusive breastfeeding for the first 6 months of life and continued with the introduction of complementary food by continuing to provide breast milk until the age of 2 years old.

This was in accordance with a study done byHariani et al.,(2016), which stated that there was a relationship between complementary feeding pattern and baby growth.The better the pattern of complementary feeding, the better the growth chart of the toddlers. This was also in accordance with a study done by Lestari et al. (2014) and Dewi et al. (2010), which stated that there was a relationship between complementary feeding pattern and child nutritional status. The provisions of good breastfeeding were the on time schedule which was $\geq 6$ months, the appropriate frequency, and the appropriate form of food would affect the toddlers' nutritional status.

\section{The Effect of Relationship between Maternal Education on Child Nutritional Status.}

In this study, most of the mothers who were the subjects of this research had high level of education ( $\geq \mathrm{HS}$ ). In addition, maternal education has a positive and indirect effect on toddlers nutritional status. The level of someone's knowledge was closely related to educational background. The higher the level of education, the better the feeding behavior. The level of education played a role in the process of absorbing the knowledge of nutrition obtained especially for the mothers. Good knowledge would have an impact on children's nutritional status. Adequate nutritional status would have an impact on the health and welfare and also the life of future generations (Maria and Rahmadeni, 2014). According to a study done by Semba et al., (2008), maternal education affected child nutritional status. Mothers with high level of education would affect the parenting and feeding.

This was in line with a study done by Vollmer et al. (2015), which stated that parents' education affected the nutritional status. The higher the parental education, the better the child nutritional status. The prevalence of stunting, underweight, and wasting was lower in both parents who had higher education compared to the parents who had low level of education.

Parents' education, especially mothers, was very influential in preventing malnutrition among toddlers. Mothers who have high or good education can provide good care for their children, they would also have behavior in realizing better health and improve maternal knowledge about nutrition in children. In addition, highlyeducated mothers would be able to process and provide nutritious food for children and were able to decide the best care for the toddlers (AmbadekarandZodpey, 2016).

High level of education would also affect family income so that it affected the provision of nutritious food. This was in accordance with a study done byNurlila (2011), which stated thatthe income received by a person was affected by the education pursued. Higher education would have a better chance of getting better employment and greater income. High education and large income would reduce the risk of experiencing malnutrition in toddlers.

\section{The Effect of Relationship between Family Income on Toddlers' Nutritional Status.}

In this study, most of the mothers who were the subjects of this research had high

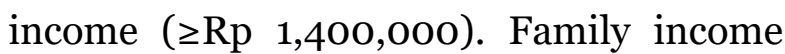
has a direct and positive effect on toddlers nutritional status. Low family income could affect the fulfillment of nutritious or good 
quality food, which affected the nutrition of toddlers. A study done byNurlila (2011), stated that there was a relationship between family income and malnutrition. Children from low family income were 16.62 times more likely to have malnutrition compared to toddlers who have high or adequate family income. This was also in accordance with a study done by Persulessy et al. (2013) which stated that there was an effect of family income on child nutritional status.Parents who have low family income were 4 times more likely to have toddlers with malnutrition than parents with high family income.

Income brought a strong impact or effect on nutritional status. Every increase in income has a direct impact on the fulfillment of food for both the mother and fetus. Fulfillment of sufficient food would affect the baby's birth weight. In addition, income was the factor that determined the quality and quantity of food. If the level of income rised, the amount and type of food would be good and nutritious (Wirawanand Rahmawati, 2016).

\section{The Effect of Relationship between Birth Weight on Child Nutritional Status}

The results of path analysis showed that birth weight has a direct and positive effect on toddlers' nutritional status. According to a study done by Ambadekar and Zodpey (2016), it was stated that low birth weight $(<2,500 \mathrm{~g})$ was related to the incidence of malnutrition (malnutrition, stunting, and skinny). Children with low birth weight were 3.4 times more likely to experience malnutrition than toddlers who have normal birth weight. According to Rachmi et al., (2016), low infant birth weight was associated with toddlers' nutritional status, and the toddlers who were born with low birth weight $(<2,500 \mathrm{~g})$ were more likely to be underweight than toddlers who have normal birth weight.

A study done by Pramono and Putro (2009) stated that low maternal education affected the infants, low-educated mothers were 1.55 times more likely to have babies with low birth weight than highly-educated mothers. Inadequate or insufficient knowledge about balanced nutrition intake resulted in wrong consumption behavior, which affected the nutritional status of pregnant women, both before and during pregnancy, and it could lead to low birth weight.

The limitations in this study were that this study was conducted retrospectively in which the mothers must recall previous or past events so that it increased the risk of bias. In addition, the instrument of data collection used in this study was questionnaire and it required quite a long time ( \pm 15 minutes), so that the research subjects were likely to experience saturation in filling out the questionnaire.

From the results of this study, it can be concluded that there was a direct effect of complementary feeding pattern, family income, and birth weight on toddlers' nutritional status. In addition, there was an indirect effect of maternal education on toddlers' nutritional status through family income variable.

The suggestions for the Klaten District Health Office were to provide a counseling corner for the mothers, family, and community about how to provide food for toddlers which in accordance with their age, along with the demonstration of the process. In addition, it was also necessary to establish a cooperation with the village apparatus and health cadres in supporting the assistance and counseling to mothers and families during the first 1000 days of life, therefore, thechild growth and development can be monitored. 


\section{REFERENCES}

Ambadekar NN, Zodpey SP (2016). Risk factors for severe acute malnutrition in under-five children: a case-control study in a rural part of india. Public Health Journal, 142: 136-143.

Dewi RK, Handayani R, Pantiawati I (2011). Hubungan pola pemberian makanan pendamping asi (mp-asi) dengan status gizi balita usia 6-12 bulan di Desa Kaliori Kecamatan Kalibagor Kabupaten Banyumas. Jurnal Ilmiah Kebidanan, 2 (1): 97-110.

Dinas Kesehatan Kabupaten Klaten (2015). Profil Kesehatan Kabupaten Klaten tahun 2015. Dinas Kesehatan Kabupaten Klaten.

(2016). Rekapitulasi status gizi balita kabupaten klaten. Dinas Kesehatan Kabupaten Klaten.

Dinas Kesehatan Provinsi Jawa Tengah. (2012). Profil kesehatan provinsi jawa tengah tahun 2012. Dinas Kesehatan Provinsi Jawa Tengah.

Hariani RE, Amareta DI, Suryana AL (2016). Pola pemberian asi dan makanan pendamping asi terhadap grafik pertumbuhan pada kartu menuju sehat (kms). Jurnal Ilmiah Inovasi, 1 (1): 41-46.

International Food Policy Research Institute (IFPRI) (2016). Global nutrition report 2016: from promise to impact ending malnutrition by 2030. Washington DC.

Kementerian Kesehatan RI dan Unicef (2013). Paket konseling: pemberian makan bayi dan anak. Jakarta: Kementerian Kesehatan Republik Indonesia.

Kementerian Kesehatan RI (2013). Hasil riset kesehatan dasar (Riskesda) tahun 2013. Jakarta: Kementrian Kesehatan Republik Indonesia.
Kementerian Kesehatan RI (2016). Situasi Balita Pendek. Jakarta: Pusat Data dan Informasi Kementerian Keseha$\tan \mathrm{RI}$.

Lestari MU, Lubis G, Pertiwi D (2014). Hubungan pemberian makanan pendamping asi dengan status gizi anak usia 1-3 tahun di kota padang. Jurnal Kesehatan Andalas, 3(2): 188-190.

Maria RD, Rahmadeni S (2014). Hubungan pengetahuan ibu tentang variasi makanan dengan status gizi balita di wilayah kerja puskesmas mandiangin kota bukittinggi tahun 2014. Jurnal Kesehatan STIKes Prima Nusantara Bukittinggi, 5 (2): 21-25.

Murti B (2011). Kesehatan anak dan epidemiologi sepanjang hayat. Jurnal Kedokteran Indonesia. 2(1).

Nurlila RU (2011). Faktor penyebab gizi buruk pada anak balita di wilayah kerja puskesmas mata kota kendari. Jurnal Studi Ilmu Sosial IAIN Kendari. Page: 102-115. ISSN 0852-5358.

Persulessy V, Mursyid A, Wijanarka A (2013). Tingkat pendapatan dan pola makan berhubungan dengan status gizi balita di daerah nelayan distrik jayapura utara kota jayapura. Jurnal Gizi dan Dietetik Indonesia, 1(3): 143150.

Pramono M, Putro G (2009). Risiko terjadinya berat bayi lahir rendah menurut determinan sosial, ekonomi dan demografi di indonesia. Buletin Penelitian Sistem Kesehatan. 12(2): 127132.

Semba RD, de Pee S, Sun K, Sari M, Akhter $\mathrm{N}$, Bloem MW (2008). Effect of parental formal education on risk of child stunting in indonesia and bangladesh: a cross-sectional study. Lancet, 371: 322-328.

Vollmer S, Bommer C, Krisna A, Harttgen K, Subramanian SV (2015). The asso- 
Journal of Maternal and Child Health (2016), 1(3): 170-178

https://doi.org/10.26911/thejmch.2016.01.03.04

ciation of parental education with childhood undernutrition in low and middle income countries: comparing the role of paternal and maternal education. International Journal of Epidemiology: 1-12. DOI: 10.1093/ije/dyw133.
Wirawan NN, Rahmawati W. (2016). Ketersediaan dan keragaman pangan serta tingkat ekonomi sebagai prediktor status gizi balita. Indonesian Journal of Human Nutrition. 3(1): 80-90. PISSN 2442-6636 